\title{
Management of Massive Hemorrhage after Percutaneous Nephrolithotomy: Angioembolization or Renorrhaphy
}

\section{Perkütan Nefrolitotomi Sonrası Masif Kanamaların Tedavisi: Angioembolizasyon ve Renorafi}

\author{
Murat Tuncer1, Gökhan Faydacı1, Bilal Eryıldırım1, Emre Çamur1, Elif O. Tuncer2, \\ Feyyaz Baltacıoğlu3, Aydın Özgül1, Kemal Sarıca1
}

1Dr. Lütfi Kırdar Kartal Training and Research Hospital, Clinic of Urology, İstanbul, Turkey

2 Medeniyet University Faculty of Medicine, Department of Radiology, Istanbul, Turkey

3Marmara University Faculty of Medicine, Department of Radiology, İstanbul, Turkey

\section{What's known on the subject? and What does the study add?}

It is known that renal angiography and embolization is an effective and safe method in massive bleeding after percutaneous nephrolithotomy. In our study, we found that renal angiography is superior to renorraphy.

\begin{abstract}
Objective

We present two treatment modalities, selective renal angioembolization and renorraphy, in massive renal hemorrage after percutaneous nephrolithotomy (PCNL) that could not be controlled by conservative methods.

\section{Materials and Methods}

One thousand two-hundred patients, who had undergone PCNL between January 2003 and February 2014, were retrospectively reviewed. From these cases, we selected patients with massive post procedural bleeding that could not be taken under control by conservative methods and we reviewed their clinical course and treatment results.
\end{abstract}

\section{Results}

Bleeding could not controlled by conservative methods in 6 patients and angioembolization was done succesfully. In 3 patients, angioembolization was not available. Renorraphy was performed in 2 patients and nephrectomy in 1 patient at first attempt. Renorraphy could not solve the problem of massive hemorrage and these 2 patients eventually underwent nephrectomy.

\section{Conclusion}

Renal angiography and embolization is an effective and safe method and renorraphy should not be the first option in massive bleeding after PCNL that can not be taken under control by conservative methods.

\section{Keywords}

Percutaneous nephrolithotomy, bleeding, embolization, renorraphy

\section{ÖZ}

Amaç

Perkütan nefrolitotomi (PNL) sonrası konservatif yöntemlerle kontrol altına alınamayan masif kanamalarda uygulanan selektif angioembolizasyon ve renorafi tedavi yöntemlerini sunmayı amaçladık.

Gereç ve Yöntem

Ocak 2003 ile Şubat 2014 arasında PNL yapılan 1,200 hasta retrospektif olarak incelendi. Girişim sonrası masif kanaması olan ve konservatif yöntemlerle kontrol edilemeyen hastalar çalışmaya alındı ve klinik gidişatları ile tedavi sonuçları sunuldu.

\section{Bulgular}

Kanaması konservatif yöntemlerle durmayan 6 hastaya başarılı bir şekilde angioembolizasyon yapıldı. Angioembolizasyon 3 hastaya yapılamadı. İki hastaya renorafi ve 1 hastaya ise direkt nefrektomi yapıldı. Renorafi yapılan 2 hastada masif kanama devam etmesi üzerine bu hastalara nefrektomi yapılmak zorunda kalındı.

\section{Sonuç}

PNL sonrası konservatif yöntemlerle durdurulamayan masif kanamalarda renal angioembolizasyon etkili ve güvenli bir yöntemdir, renorafi ilk seçenek olmamalıdır.

\section{Anahtar Kelimeler}

Perkütan nefrolitotomi, kanama, embolizasyon, renorafi

\section{Correspondence}

Murat Tuncer MD, Dr. Lütfi Kırdar Kartal Training and Research Hospital, Clinic of Urology, İstanbul, Turkey

Phone: +90 21644139 00/18 07 E-mail: drmurattuncer@hotmail.com Received: 28.10.2015 Accepted: 10.11.2015 


\section{Introduction}

Since the need for open surgery is observed in only $0.7-4 \%$ of cases, percutaneous nephrolithotomy (PNL) is a standard surgical procedure that has taken its place in the treatment of kidney stones (1). However, complications of PNL cannot be completely avoided. Although PNL is a procedure with a low morbidity, a complication may develop in one of every 4 patients following the procedure (2). Renal bleeding is one of the most dangerous complications of PNL. In recent reports, clinically significant bleeding that requires transfusion was reported at a rate of $8-37 \%(3,4)$. Conservative methods are generally sufficient to stop bleeding in many patients although renal angioembolization is required in less than 1\% of patients (5). Renorraphy and nephrectomy are alternative options in patients who cannot undergo angioembolization (6).

In this study, we aimed to present our experiences with the patients in whom bleeding could not be stopped by conservative methods and underwent selective renal angioembolization and open surgery following PNL.

\section{Materials and Methods}

Ethics committee approval was taken from our hospital for the implementation of this study. One thousand two-hundred patients, who underwent PNL operation in our clinic between January 2003 and February 2014, were retrospectively evaluated. Entry was performed simultaneously under ultrasonography (USG) guidance in 975 cases and with fluoroscopy in 225 patients and a 12-F-14-F malecot nephrostomy catheter was inserted into the system in all cases during the operation. Patients, who had a severe bleeding during postoperative period following PNL and those in whom bleeding could not be controlled by conservative methods, were included in this study.

In accordance with PNL technique that is performed in our clinic, a 5-F or 6-F open-ended ureteral catheter was placed in a retrograde fashion with the guidance of fluoroscopy in patients who did not have a dilatation in their collection system. Patients, who had dilatation in their collection systems, were directly brought to the prone position; appropriate calyx was chosen for the entry under the guidance of perioperative USG; and under USG guidance, the collection system was entered by an 18-gauge needle by a urology team. Then, a softended guidewire was placed into the system and a dilatation was provided up to 30-F in 860 patients over the guidewire using Amplatz dilators. A 30-F sheath was placed into the system and a 26-F rigid nephroscope was used. In 340 patients, dilatation was provided up to 24-F; a 24-F working sheath was placed into the system and an 18-F rigid nephroscope was used. Stones were fragmanted by pneumatic or ultrasonic lithotripter and the fragmanted stones were excised by stone forceps and/or irrigation. At the end of the operation, a 12$14-\mathrm{F}$ nephrostomy tube was placed into the system through access sites, and the procedure was ended after the place of the tube was confirmed under fluoroscopy.

Renal angiography and embolization procedure were performed by invasive radiology team. A 5-F vascular sheath was placed into the femoral artery under local anesthesia. Then, the renal artery at the operation site was selectively catheterized with the catheter and diagnostic images were taken by the administration of contrast material. In patients who were found to have pseudoaneurysm or arteriovenous fistula, bleeding artery of the lesion was embolized by platinium metalic coil.

Patients who underwent renorraphy were put in the flank position; the renal pedicle was reached by retroperitoneal approach and the pedicle was controlled. Perirenal hematoma was emptied and percutaneous entry sites were found. Bleeding control was achieved by suturing in accordance with renal laceration repair technique with 2/0 vicryl. Coagulant agent spongostan was placed on the suture line and Gerota's fascia was closed and the operation was ended. An 18-F drain was placed into the retroperitoneal space. Although there was no drainage from the retroperitoneal space in two of the patients who underwent renorraphy at 6 and 8 hours during early postoperative period, massive hematuria began through transurethral catheter and hemodynamics were disrupted. Nephrectomy was performed in patients whose hemodynamics did not improve and whose hematuria continued following renorraphy at postoperative $10^{\text {th }}$ and $12^{\text {th }}$ hours. The patients were discharged at postoperative days 4 and 5 following nephrectomy.

\section{Results}

Out of 1.200 PNL cases in our clinic, postoperative bleeding could not be stopped by conservative methods in 9 patients $(0.75 \%)$. The cases enrolled in the study were aged 25 to 58 years. PNL was performed on the left side in 5 and on the right side in 4 cases. Six patients were men and 3 were women; and 2 patients had a history of previous operation on the same side. $2^{\text {nd }}$ entry was needed in only two cases, and single entry was done in the others. Entries were performed through lower and middle calyces in patients who were applied 2 entries. The mean stone size was $540 \mathrm{~mm}^{2}$ (200-1200 mm²). The clinical and demographic characteristics of patients are given in Table 1.

While bleeding requiring intervention was observed in 8 (0.9\%) of 860 cases who were operated by a $26-\mathrm{F}$ nephroscope through a conventional 30-F sheath, it was seen in just one $(0.3 \%)$ of 340 patients who were operated by an 18 nephroscope through a 24-F sheath.

Out of these cases, whose bleeding could not be terminated by conservative methods, 6 underwent selective renal angiography. The focus of bleeding was determined to be originated from the lower calyx in patients who were entered twice (Figure 1). 4 patients were intervened before discharge due to continuation of postoperative massive bleeding and decrease in Hct values despite blood transfusion. Pseudoaneurysm detected in patients following angiography and bleeding was completely stopped after coil embolization (Figure 2). Patients whose hemodynamics were found to be stable at follow ups were discharged. Other 2 patients were admitted to our clinic at postoperative days 10 and 13 with hematuria and anemia after being discharged following withdrawal of nephrostomy catheters. Bleeding was stopped by the embolization of arteriovenous fistula that was detected in renal angiography and the patients were discharged when their hemodynamics became stable.

The reason in 2 patients, in whom angioembolization could not be performed and underwent renorraphy, was inability to arrive 


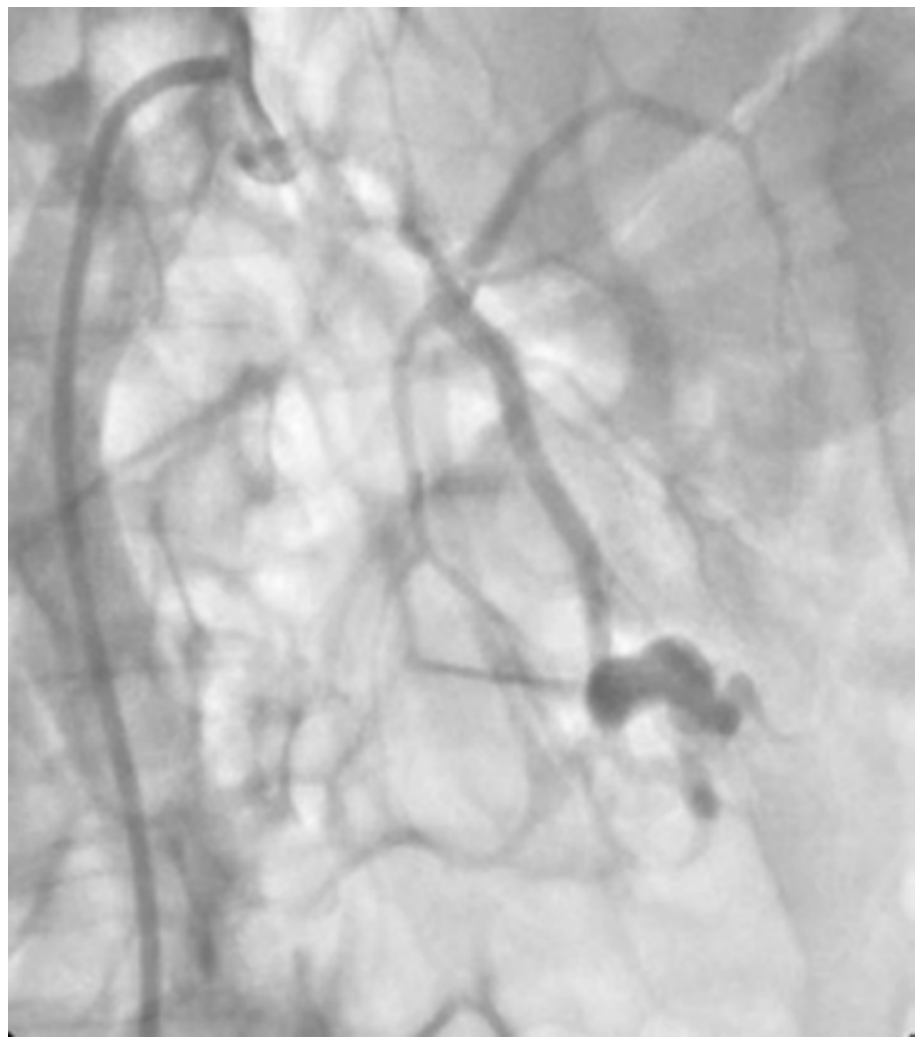

Figure 1. Selective renal angiography showing active bleeding

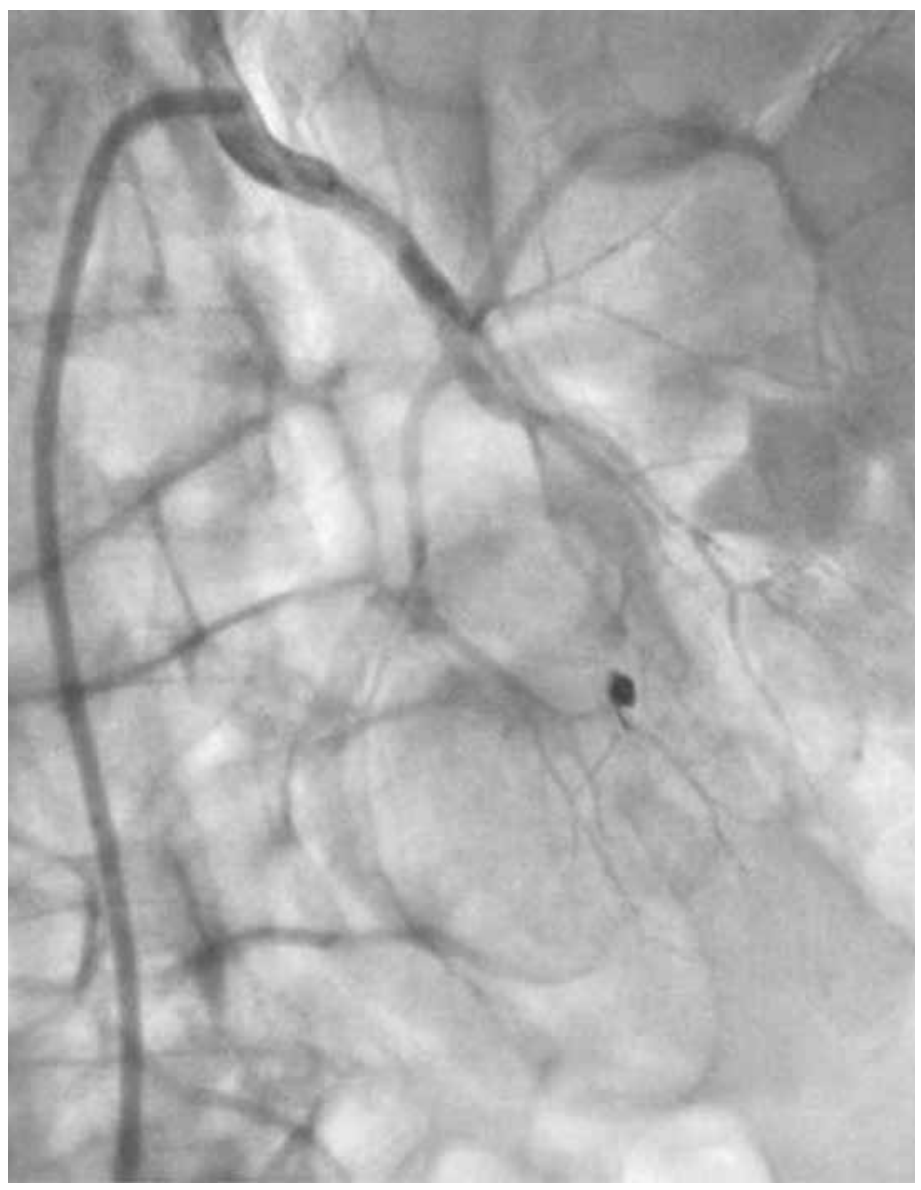

Figure 2. Appearance after selective renal angioembolization angioembolization unit on time. The patients who underwent renorraphy were brought into the flank position. The renal pedicle was controlled by retroperitoneal approach; then hematoma was emptied by opening Gerota's fascia and percutaneous entry sites were found. There was one midline entry in each of two patients who underwent renorraphy. The entry sites were sutured with $2 / 0$ vicryl in accordance with the renal laceration repair tehnique. However, massive hematuria continued in both patients following renorraphy and their hemodynamics were disrupted. These patients underwent nephrectomy due to inability to reach angioembolization unit and the disruption of hemodynamics.

Massive hematuria developed in the patient who underwent direct nephrectomy at postoperative 6 hours. Renal angiography unit could not be reached and the patient was urgently operated for renorraphy due to the worsening of hemodynamics despite blood transfusions; nephrectomy was performed due to bleeding from the access site and following continuation of hematuria despite renorraphy. The patient was brought to intensive care unit postoperatively. This patient, who developed disseminated intravascular coagulation, died at postoperative day 2 .

\section{Discussion}

PNL has taken the place of open surgery in the treatment of big, multiple and staghorn kidney stones. However, it has still unpreventable complications. Its one of the most severe complications is renal bleeding (1). Renal vascular damages are frequently seen during PNL and they require blood transfusions at a rate of 3-23\% $(3,7)$. Richstone et al. (8) have reported massive bleeding that requires angioembolization in 57 patients (1.2\%) in a percutaneous renal surgery series including 4.695 patients.

Pathology leading to massive post-procedural bleeding may be during needle insertion, dilatation or nephroscopy. Diabetes, staghorn stone, dilatation method, number of access and stone size are the reported risk factors for bleeding $(9,10)$. El-Nahas et al. (11) have indicated solitary kidney, number of access, upper pole entry and staghorn stone as the risk factors for bleeding that requires angioembolization besides the experience of the surgeon in a series of 3.878 patients. It is necessary to follow some rules during PNL in order to decrease surgical risk factors. Correct renal entry is an important factor in successful stone removal and minimizing the risk of bleeding. Ideal access path is the fornix of the posterior calyx that is located most peripherally and this decreases the damage to renal parenchyma and large vessels. Another condition requiring attention is punctures that are through the infundibulum or in media/center. Both of these can increase the risk for injury to segmental and lobar arteries (12). It is required to take attention to sequential dilatation in order to decrease renal vessel injury and balloon dilatation is preferentially used. Safak

\section{Table 1. Demographic characteristics of the patients}

\begin{tabular}{|l|l|l|}
\hline & Angioembolization & $\begin{array}{l}\text { Renorraphy/ } \\
\text { Nephrectomy }\end{array}$ \\
\hline Number of patients & 6 & 3 \\
\hline Age (years), mean & $25-58(45)$ & $23-52(38.3)$ \\
\hline Laterality (right/left) & $3 / 3$ & $2 / 1$ \\
\hline Stone size $\left(\mathrm{mm}^{2}\right)($ mean) & $250-1200(541,6)$ & $350-800(550)$ \\
\hline
\end{tabular}


et al. (13) have reported less need for transfusion in balloon dilatation compared to Amplatz dilatation. The experience of the surgeon is an important factor in following the rules that need attention in order to decrease surgical risk factors. Four of our cases were operated in 2006 and 3 of the operations were performed by the same surgeon who was less experienced at that time although the materials and techniques used were the same.

Helal et al. (14) have first developed a "miniperc" technique for children to decrease the disadvantages of conventional PNL. In a recent study by Mishra et al., (15) it was indicated that mean hemoglobin decrease was less in "miniperc" compared to standard PNL and no patient underwent blood transfusion in "miniperc" group whereas 1 patient required blood transfusion in standard PNL group. However, the duration of operation has significantly increased. In our series, only 1 patient in 340 cases, who underwent mini PNL, presented with massive bleeding requiring angioembolization. We think that miniperc method can decrease the incidence of bleeding and transfusion.

In only $1 \%$ of the patients, bleeding cannot be stopped by conservative methods and angioembolization is required following PNL (5). Bleeding is mostly venous and it stops by the tamp effect of nephrostomy tube that is inserted after the procedure. If bleeding continues despite this, we clamp nephrostomy tube and wait for 1 hour in our practice. Then, we observe that bleeding is mostly stopped when nephrostomy tube is opened. If bleeding goes on, we tampon the lumbar region and we clamp nephrostomy tube again for 1-2 hours and we perform hemodynamics follow-up. If conservative methods fail, renal angioembolization is the most effective type of treatment. The pathologies are pseudoaneurysm (50\%), arteriovenous fistula (25\%) and isolated renal artery damage (25\%) (8). Rupture of pseudoaneurysm may cause late bleedings. Angioembolization is a successful and effective method in the termination of bleeding in 95\% of cases (8). In our study, bleeding was completely stopped in all 6 patients who underwent renal angioembolization following the procedure, and the patients were discharged without problems at follow-ups.

Although angioembolization is a very successful method, it may not succeed in 5\% of cases (8). In some conditions, this procedure may not be available or worsening hemodynamics of the patient may not leave time for this procedure. There are few publications in the literature about renorraphy in massive bleedings following PNL. Aminsharifi et al. (6) have performed open surgical exploration in 8 patients who could not undergo angioembolization for various reasons, and they have performed partial nephrectomy in 2 and renorraphy in 6 of them (6). They could maintain hemostasis in patients who underwent renorraphy and they discharged the patients without experiencing any severe postoperative problems. Nephrectomy is still an intervention that is often performed in high-grade renal traumas $(16,17)$. Nephrectomy rates in grade 4-5 penetrating and blunt injuries are 54\% and 83\%, respectively (17). Direct nephrectomy was required in one of our patients and in the other two patients, in whom renorraphy failed, it was then required to perform nephrectomy. The approach in these cases was based on the principles of grade 4-5 renal trauma approach. We think that the reason for failure in renorraphy was segmental vessels associated with damage which was formed on the calyx neck or bleedings from interlobar vessels due to damage to the infundibulum. Hemostasis sutures that would be performed on parenchyma may not provide sufficient control of bleedings that occur in these vessels.

\section{Conclusion}

It is crucial to give attention to risk factors in order to decrease the risk of bleeding during and following PNL. In case of a bleeding that cannot be stopped by conservative methods after PNL, renal angioembolization, that is a very effective treatment method, should be performed as soon as possible. There is less information in the literature about the efficiency of open surgery and renorraphy in patients who cannot undergo angioembolization. We accept that the number of our cases is less to draw conclusion on the success of exploration and renorraphy, but we aimed to present our experiences on this subject. As the number of publications about renorraphy increases, the efficiency of renorraphy will be evaluated more accurately.

\section{Authorship Contributions}

Ethics Committee Approval: The study were approved by Dr. Lütfi Kırdar Training and Research Hospital of Local Ethics Committee, Informed Consent: Consent form was filled out by all participants, Concept: Murat Tuncer, Kemal Sarica, Design: Murat Tuncer, Feyyaz Baltacıoğlu, Data Collection or Processing: Emre Çamur, Elif O. Tuncer, Analysis or Interpretation: Bilal Eryıldırım, Literature Search: Murat Tuncer, Aydın Özgül, Writing: Murat Tuncer, Gökhan Faydacl, Peerreview: Internal peer-reviewed, Conflict of Interest: No conflict of interest was declared by the authors, Financial Disclosure: The authors declared that this study has received no financial support.

\section{References}

1. Preminger GM, Assimos DG, Lingeman JE, Nakada SY, Pearle MS, Wolf JS Jr; AUA Nephrolithiasis Guideline Panel. Chapter 1: AUA guideline on management of staghorn calculi: diagnosis and treatment recommendations. J Urol 2005;173:1991-2000.

2. Desai M, De Lisa A, Turna B, Rioja J, Walfridsson H, D'Addessi A, Wong C, Rosette On Behalf Of The Croes Pcnl Study Group J. The clinical research office of the endourological society percutaneous nephrolithotomy global study: staghorn versus nonstaghorn stones, J Endourol 2011;25:12631268.

3. Srivastava A, Singh KJ, Suri A, Dubey D, Kumar A, Kapoor R, Mandhani A, Jain $S$. Vascular complications after percutaneous nephrolithotomy: are there any predictive factors? Urology 2005;66:38-40.

4. Silverstein $A D$, Terranova $S A$, Auge $B K$, Weizer $A Z$, Delvecchio $F C$, Pietrow PK, Munver R, Albala DM, Preminger GM. Bilateral renal calculi: assessment of staged $v$ synchronous percutaneous nephrolithotomy. J Endourol 2004;18:145-151.

5. Tefekli A, Ali Karadag M, Tepeler K, Sari E, Berberoglu Y, Baykal M, Sarilar 0, Muslumanoglu AY. Classification of percutaneous nephrolithotomy complications using the modified clavien grading system: looking for a standard. Eur Urol 2008;53:184-190.

6. Aminsharifi A, Irani D, Eslahi A. Massive hemorrhage after percutaneous nephrolithotomy: saving the kidney when angioembolization has failed or is unavailable. Int J Surg 2014;12:872-876.

7. Martin $X$, Murat FJ, Feitosa LC, Rouvière 0 , Lyonnet $D$, Gelet $A$, Dubernard J. Severe bleeding after nephrolithotomy: results of hyperselective embolization. Eur Urol 2000;37:136-139.

8. Richstone L, Reggio E, Ost MC, Seideman C, Fossett LK, Okeke Z, Rastinehad $A R$, Lobko I, Siegel DN, Smith AD. First prize (tie): hemorrhage following percutaneous renal surgery: characterization of angiographic findings, $J$ Endourol 2008;22:1129-1135. 
9. Akman $T$, Binbay $M$, Sari E, Yuruk E, Tepeler A, Akcay M, Muslumanoglu AY, Tefekli A. Factors affecting bleeding during percutaneous nephrolithotomy: single surgeon experience. J Endourol 2011;25:327333.

10. Turna B, Nazli O, Demiryoguran S, Mammadov R, Cal C. Percutaneous nephrolithotomy: variables that influence hemorrhage. Urology 2007;69:603-607.

11. El-Nahas AR, Shokeir AA, El-Assmy AM, Mohsen T, Shoma AM, Eraky I, El-Kenawy MR, El-Kappany HA. Post-percutaneous nephrolithotomy extensive hemorrhage: a study of risk factors. J Urol 2007;177:576-579.

12. Lewis $S$, Patel U. Major complications after percutaneous nephrostomylessons from a department audit. Clin Radiol 2004;59:171-179.

13. Safak M, Gögüş $C$, Soygür T. Nephrostomy tract dilation using a balloon dilator in percutaneous renal surgery: experience with 95 cases and comparison with the fascial dilator system. Urol Int 2003;71:382-384.
14. Helal M, Black T, Lockhart J, Figueroa TE. The Hickman peel-away sheath: alternative for pediatric percutaneous nephrolithotomy. J Endourol 1997;11:171-172.

15. Mishra S, Sharma R, Garg C, Kurien A, Sabnis R, Desai M. Prospective comparative study of miniperc and standard PNL for treatment of 1 to 2 cm size renal stone. BJU Int 2011;108:896-899.

16. Hotaling JM, Sorensen MD, Smith TG 3rd, Rivara FP, Wessells H, Voelzke BB. Analysis of diagnostic angiography and angioembolization in the acute management of renal trauma using a national data set. J Urol 2011;185:1316-1320.

17. McClung CD, Hotaling JM, Wang J, Wessells H, Voelzke BB. Contemporary trends in the immediate surgical management of renal trauma using a national database. J Trauma Acute Care Surg 75 2013;75:602-606. 